\title{
AGRICULTURAL SECTOR IN ECONOMY OF POLAND IN 1950-2020.
}

\author{
Stanisław Kowalczyk ${ }^{1}$, Mariola Kwasek ${ }^{2}$
}

\begin{abstract}
Agriculture constitutes one of the first and foremost forms of conscious and organised human activity. Its importance for the society and for the economy stems from its main purpose, namely to meet one of the basic human needs - to satisfy hunger. The period of almost 70 years under consideration brought about exceptional change in the case of Polish agriculture. It consisted of a systematic decline in the potential of agriculture in the economy. The factor that is specific to agriculture - land, evolved relatively the least. Land allocated for agricultural purposes reduced for about one quarter. Much deeper changes have taken place in the other two factors, universal from the point of view of the sectoral application, namely work (human resources) and capital.

In the post-war period, trade in agri-food products, albeit small, remained of great importance for the development of Polish agriculture and the entire economy. The nature of the links in this area has also undergone significant changes. Since Poland's accession to the European Union, the balance in foreign trade in agri-food products has been positive and has been growing steadily. This means that foreign customers are becoming increasingly interested in agricultural and food products from Poland. The strategic directions of development for Polish agriculture are the production of bovine meat, poultry meat, eggs, milk and milk products, butter, sugar, fruits, vegetables, pulses, potatoes and cereals. Food consumption has also undergone dynamic changes. The main goal of the paper is to define the position of agriculture in the national economy at various stages of development, as well as changing external conditions, including political, social and economic, which affect this position.
\end{abstract}

Key words: Agriculture, economy, trade, food consumption, Poland.

JEL $^{3}:$ E20, F14, O13

1 Stanisław Kowalczyk, Ph.D. hab., Full Professor, Institute of Agricultural and Food Economics - National Research Institute (IAFE-NRI), Świętokrzyska Street no. 20, Warsaw, Poland, Phone: +48 2250544 49, E-mail: stanislaw.kowalczyk@ierigz.waw.pl

2 Mariola Kwasek, Ph.D. hab, Associate Professor, Institute of Agricultural and Food Economics - National Research Institute (IAFE-NRI), Świętokrzyska Street no. 20, Warsaw, Poland, Phone: +48225054646 E-mail: mariola.kwasek@ierigz.waw.pl

3 Article info: Original Article, Received: 19 $9^{\text {th }}$ October 2020, Accepted: $8^{\text {th }}$ November 2020. 


\section{Introduction}

The role of agriculture in shaping the nature and image of the economy and society has changed over time. However, no matter where agriculture is nowadays, its role derives from the fact that it was an original and fundamental economic sector. It was therefore also the only economic sector capable of generating the economic surplus necessary for further development, including industrial development (Byrne, 1955; Woś, 1979).

The question of the place of agriculture in the economy and society has been present for at least 250 years. This dispute, as Lains and Pinilla (2009) claim, takes place mainly between disciplines such as economic theory and economic history. In economic theory, agriculture is presented from many different perspectives. Three of them are crucial: 1) relations between agriculture and other sectors of the economy and, more broadly, its economic and social environment, 2) main forces shaping the mechanism of change and development of agriculture (drivers of change, drivers of growth), and 3) main directions (paths) of changes in agriculture.

As economic growth progresses, the importance of agriculture in the economy as measured by its share in the potential and the production and accumulation (income) effects is decreasing. This process began in the most developed countries as early as 200 years ago (Great Britain, the Netherlands, or Belgium), and gained significant acceleration after 1950 (Grigg, 1992). It should be stressed, however, that it is a relative decline. At the same time, agricultural production, followed by food production, grew continuously. For example, the GDP of world agriculture between 1970 and 2017 increased 3.3 times, while the share of agriculture in world GDP at that time fell from $5 \%$ to $3.9 \%$, i.e. by over $25 \%$ (FAO, 2019). However, in areas such as environmental quality or food security, for example, the role and importance of agriculture goes far beyond what is illustrated by its contribution to GDP.

The forces shaping the mechanism of change and development of agriculture occur at different levels of impact. They generally relate to global, national and local scale (Hazell, Wood, 2008). The driving forces on a global scale are international trade, falling food prices under the influence of agricultural productivity growth and international regulations (WTO or OECD). National forces include, in turn, changes in gross domestic product (GDP) per capita levels, urbanisation processes, agricultural policy, integration of supply chains, environmental constraints (climate policy). And finally, local forces include demographic change, the level of health protection, agricultural property rights and guarantees, local agricultural infrastructure and market access (Hazell, Wood, 2008). 
The drivers of change in agriculture include globalisation and the international exchange liberalisation that shapes this process, vertical integration and emerging global food chains (Meijerink, Roza, 2007), changes in the organisation of production and technical efficiency (productivity) at farm level (Gautam, Faruqee, 2016), increased cooperation between farmers, (Thiagarajan, 2020), but above all, it stresses the importance of development forces such as investment in R\&D and new technologies (Hayami, Ruttan, 1985), as well as pressure from consumers and end markets, the evolution of attitudes towards food safety and quality, and growing competition from the global market (Earl et al., 2002).

The main goal of the paper is to define the position of agriculture in the national economy at various stages of development, as well as changing external conditions, including political, social and economic conditions, which affect this position.

\section{Methodology and Used Data Sources}

In the paper, the relations in the agriculture and other sectors of the Polish economy were analysed empirically. The research period covers the period of 1950-2020 ${ }^{4}$. The analysis covered such areas as the potential of agriculture in the economy (land resources, labour, capital), contribution to the creation of added value (gross national income, GNI/GDP), agricultural production, foreign trade in agri-food products, food supply, food self-sufficiency and changes in food consumption. Empirical material consisted of the data from the Statistics Poland and the FAOSTAT database.

The categories of global production, gross national income and gross domestic product were used to assess the share of agriculture in the national economy. Global agricultural production includes plant production, i.e. raw (unprocessed) products of plant origin (harvest of a given year) and livestock production, i.e. production of livestock for slaughter and raw (unprocessed) animal products and livestock growth.

Gross national income equals the sum of gross incomes of all property sectors or all domestic institutional sectors, and gross domestic product equals the sum of gross value added of all property sectors or all domestic institutional sectors or the sum of gross value added of all sections and divisions plus taxes on products and less subsidies on products.

4 The exact period of analysis as regards the issues taken into consideration depends on the availability of empirical data. Long-term comparative studies encounter many methodological difficulties. The main problem is ensuring comparability of empirical data. This is a consequence of the changes that take place in defining categories and concepts over time. 
The categories of agricultural land employed in agriculture as well as investment outlays and the value of gross fixed capital were used to measure the share of the production potential of agriculture in the economy.

Investment outlays should be understood as outlays on fixed assets, i.e. buildings and structures, machinery, technical equipment and tools, means of transport and others, including water drainage, improvement of values, (improvement) of land, or livestock (basic herd). The gross value of fixed assets is equal to the outlays incurred on purchasing or manufacturing them, without deducting consumption value (depreciation). Fixed assets do not include the value of land and the right of perpetual usufruct of land, recognized from January $1^{\text {st }} 2002$ as fixed assets.

\section{Research and Results}

\section{The economic potential of agriculture}

\section{Land}

The land used for agricultural production is referred to as Utilised agricultural area (UAA). Utilisation is understood as actual agricultural activity on land (Statistics Poland, 2020). Until 2006, the agricultural area included: arable land, orchards, meadows and pastures. Since 2007, agricultural area under Good agricultural and environmental conditions (GAEC) has been divided into: area under sowing, fallow land, permanent crops (including orchards), house gardens, permanent patches, permanent pastures and other agricultural areas (Journal of Laws, 2007). However, the difference is not significant here as the agricultural areas under GAEC in 2019 represented more than $99 \%$ of all agricultural areas.

There were significant changes in the potential of agricultural area within the analysed period (Figure 1.). In 1950, there were 20,440 thousand hectares of agricultural holdings, which accounted for $65.6 \%$ of the area of Poland, while in 2019 these covered only 14,690 thousand hectares $(47.0 \%)$. Thus, in terms of actual use, around 5,750 thousand hectares were lost. The main reasons for the reduction in the area of UAA were the urbanization objectives and the needs of other sectors of the economy, including mining (mining areas) and communication industry. 
Figure 1. The share of agricultural land in Poland (period 1950-2019)

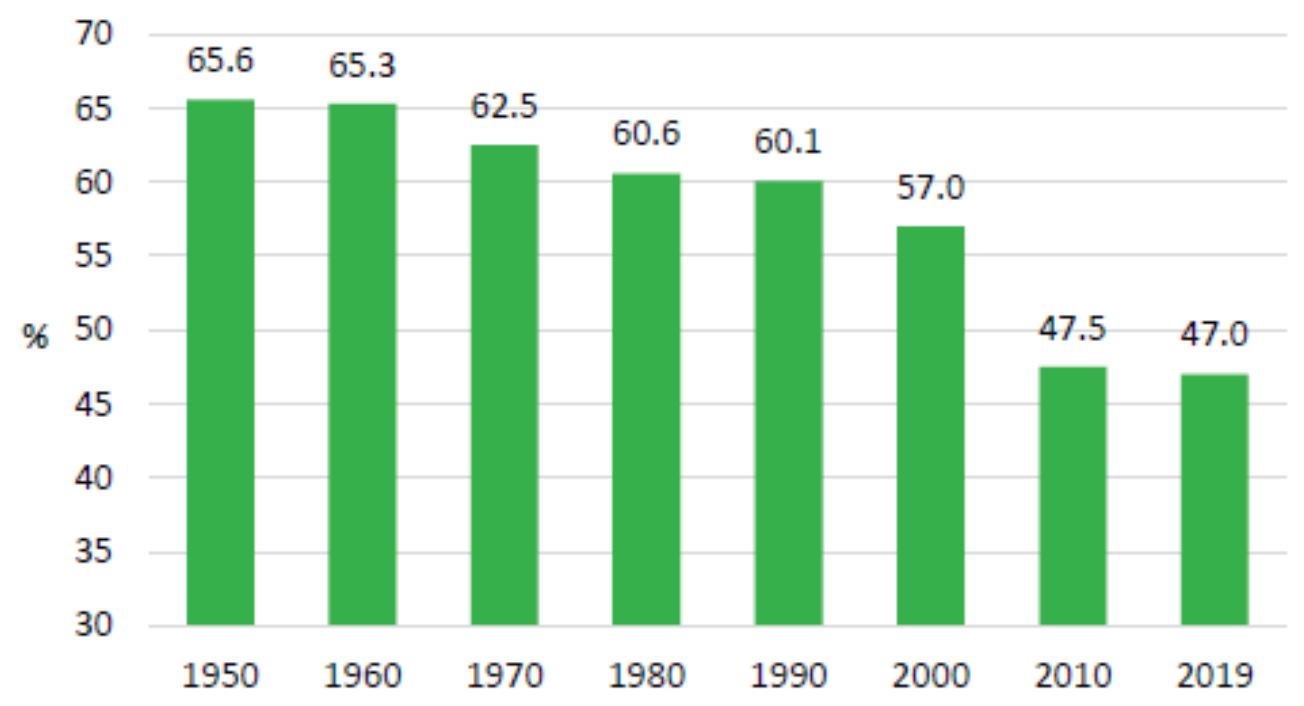

Source: Based on data from Statistics Poland, 2019.

Despite the significant urbanisation and industrial needs of recent decades, the surveying area of $\mathrm{UAA}^{5}$ still amounts to $18,760,000$ ha of UAA (Statistics Poland, 2020) and has decreased by 2\% (386,000 ha) since 2002 (Statistics Poland, 2020b). However, a significant part of that land is not currently used for agricultural production. This area not used for agricultural purposes has significantly increased after 1990, especially after Poland's accession to the EU. The areas currently not used for agricultural purposes by agricultural holdings, which are classified as UAA in geodesic terms, include permanent pastures (approximately 1,200,000 ha), land under buildings (550,000 ha), wooded areas (265,000 ha), and other land, including mainly wasteland $(810,000$ ha). Finally, it is still difficult to estimate the area of abandoned UAA, areas where the owners left the country, did not name descendants, marginal land, etc. These probably constitute an area far exceeding the one million hectares of UAA.

While in 1950 there was about 0.82 ha of UAA per statistical inhabitant of Poland, as a result of changes that have taken place over the years, in 2019 it was just 0.38 ha. However, related to food security, the current situation is much more favourable than it was 70 years ago, mainly due to technical (biological) progress determining unit productivity (yields, animal productivity) and fundamental changes in the level of agricultural intensity in the 1950s and today. However, this does not mean that the uncontrolled loss of the UAA does not pose a threat to the safety of future generations,

5 Under geodetic and cartographic law this area is categorized as agricultural land. 
which is why agricultural policy on the protection of agricultural land has been and continues to be so important.

\section{Work resources}

The factor of labour (people working in agriculture) also underwent considerable changes, even more significant than in relation to the resources of agricultural land. This is illustrated by the share of people working in agriculture in the total number of employees, as well as in the total number of inhabitants of Poland. Working person is generally a person performing work that brings them revenue or income (Statistics Poland, 2019). This category includes among others: persons employed on the basis of an employment relationship, employers and self-employed persons, including owners, co-owners and persons leasing agricultural holdings. With regard to persons working in agriculture, ignoring methodological changes that have taken place over the analysed period in this respect, Statistics Poland primarily makes estimates based on the results of general and agricultural censuses.

The share of people working in agriculture in the total number of employees has decreased radically. In 1950 it amounted to almost 70.0\%, in 1980 around 47.3\%, while in 2019 it reaches $14.4 \%$ (Figure 2.). The decrease after 1990, when the free market mechanism was restored to the Polish economy, is particularly significant. This triggered previously unknown adjustment processes, free of administrative interference, which resulted in a strong outflow from agriculture to newly created jobs in nonagricultural sectors. In addition, the privatisation of State Agricultural Farms (Państwowe Gospodarstwa Rolne, PGR) has been led to a drastic reduction in employment in the agricultural sector, where its peak (1980) accounts to around 0.5 million of employed persons.

An even greater drop in numbers has been observed as regards the relationship between people working in agriculture and the general population of Poland, from $47.2 \%$ in 1950 to $6.0 \%$ in 2019 . Thus, while in the immediate post-war period, almost every second inhabitant of Poland worked in agriculture, at present only sixteenth/ seventeenth does. These changes illustrate the scale of the phenomenon referred to in the literature as the "migration" contribution of agriculture to economic growth (Woś, 1979). 
Figure 2. Share of people working in agriculture in the total number of employees (A) and the total population (B), (period 1950-2019)

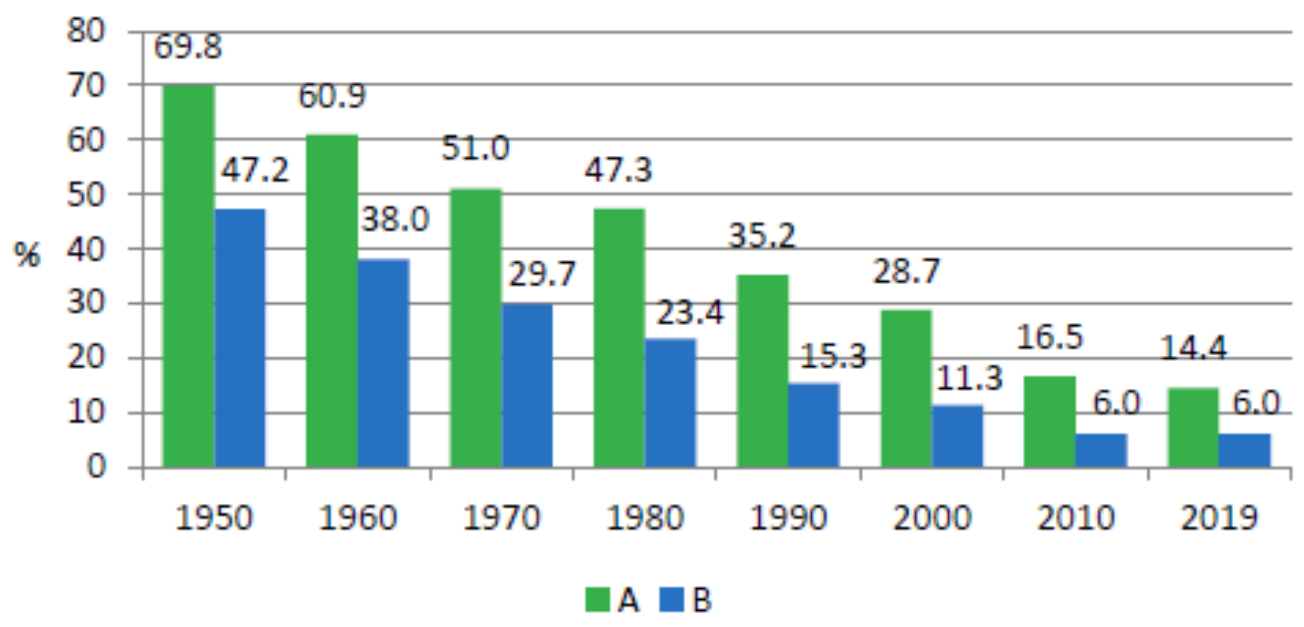

Source: Based on data from Statistics Poland, 2019.

Figure 3. Share of the population living in rural areas in the total population (period 1950-2019)

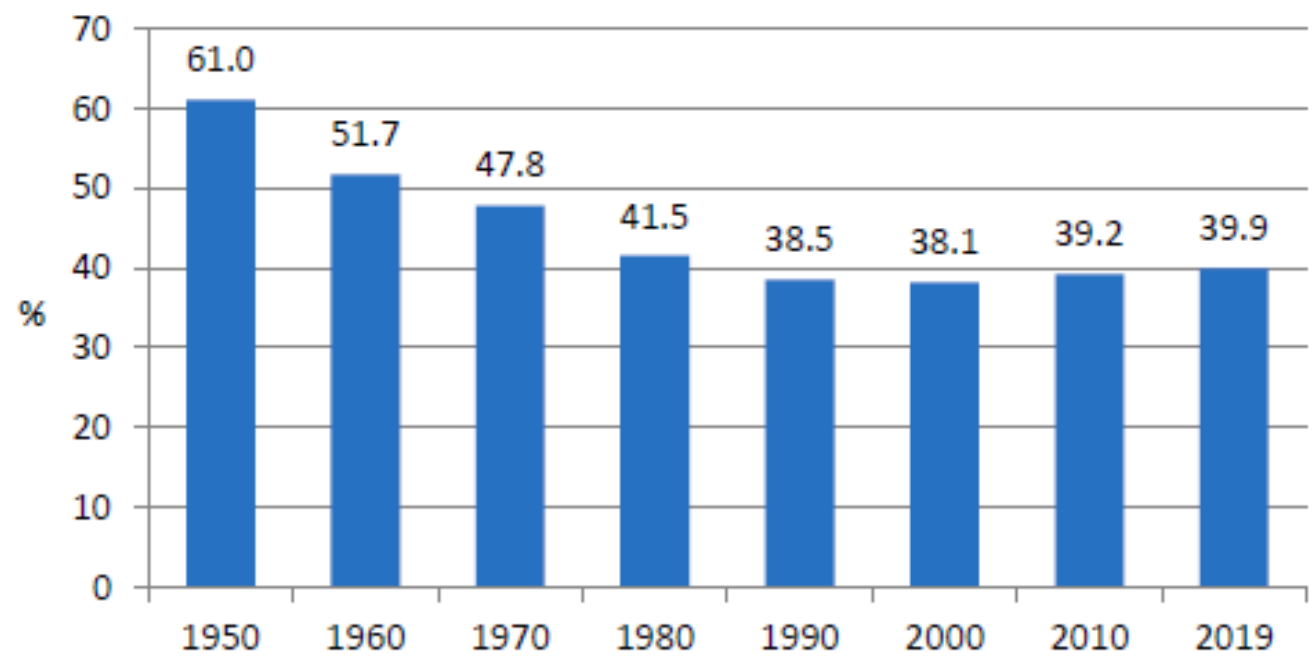

Source: Based on data from Statistics Poland, 2019.

As a result of the changes analysed above, the population living in rural areas has also been gradually decreasing. In 1950 around $61 \%$ of population lived in rural areas, while in 1990 there were only 38.5\% (Figure 3.). However, this period was 
followed by a slowdown in the outflow of population from rural areas. Recent decades have even brought a reversal of this trend in favour of rural areas.

Capital (investments, fixed assets)

Since the middle of the XX century, capital has been the most important productivitydetermining factor of production in agriculture. Its level at all times is a consequence of the resources accumulated in the past and the investments made. Agricultural inputs have changed significantly over time. This was a consequence, above all, of the agricultural policy implemented in respective decades, as well as of the general economic situation, including agriculture. Until the 1990s, the share of agriculture and hunting in investment outlays was in the range of $11-15 \%$ (Figure 4.).

Figure 4. Share of agriculture in the value of investments (A) and fixed assets (B) in total in Poland (period 1950-2018)

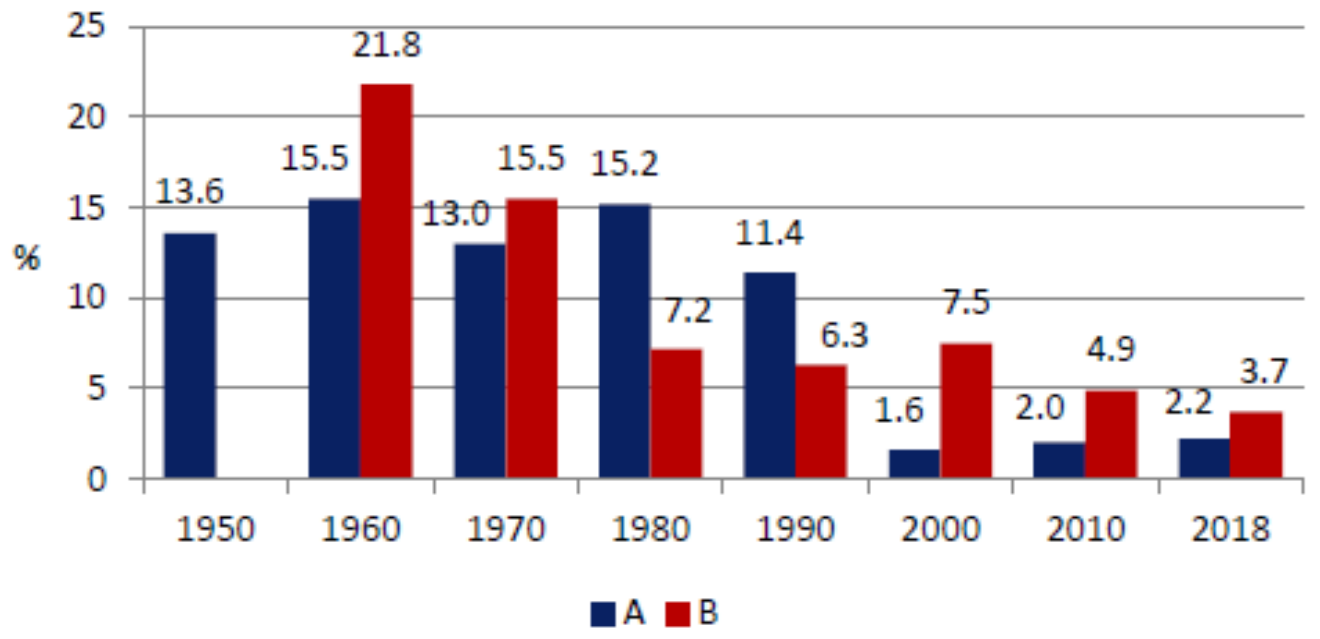

Source: Based on data from Statistics Poland, 2019.

To a large extent, these investments were carried out in the so-called socialised economy, i.e. mainly in the PGRs. For example, in the second half of the 1950s, the share of the socialised economy in agriculture ${ }^{6}$ in investment outlays constituted $58 \%$ on average. At that time, the land use structure was 15:85 for the benefit of the individual economics. The share of the public sector in agricultural investment outlays in the following years was slowly but steadily declining, and in the mid-1990s the share of the public sector in agricultural investment outlays was decreasing. In the

6 Without the so-called agricultural supply (services for agriculture), or state machinery centres (państwowe ośrodki maszynowe) and agricultural circles (kółka rolnicze). 
mid-1990s it reached the level of about 7\% (with share in the UAA area of $15.9 \%)^{7}$. Currently, it amounts to $3 \%$ (with share in the UAA area below $2.0 \%)^{8}$.

The fundamental change in the share of agriculture in investment outlays took place after 1990. This change consisted in a sudden collapse of the investment process in agriculture after the market mechanism was restored to the Polish economy. This was due to the bankruptcy of the state sector in agriculture (PGR), dissolution of many agricultural production cooperatives and economic inefficiency of a considerable proportion of individual farms. The non-agricultural sectors did not experience such collapse, as a result of which the share of agriculture in the investment outlay of the Polish economy fell below $2 \%$ in 2000 . This meant the absence of expanded reproduction of capital and a progressive decapitalisation of assets, leading to a reduction in efficiency in this sector (Kusz et al., 2013). Recent decades, especially the period after accession to the European Union, brought about a significant investment boom, mainly due to EU funds. Between 2000-2018., the level of investment expenditure in agriculture increased 2.6 times, while in the economy as a whole this increase was much smaller, around 2.3 times, as a result of which the share of agriculture in investment expenditure increased to $2.2 \%$.

The investment processes in question translated directly onto the share of agriculture in gross fixed capital formation (GFCF). While before 1960 this share was around $20 \%$, the following decades brought a gradual decline. In 1980-1990 this share was 6-7\%, while after 2000, it accounts to $4-5 \%$ (Figure 4.). This means a gradual reduction of the capital accumulated in agriculture in favour of non-agricultural sectors. This is generally quite common in modern global economy. Dynamics of non-agricultural sectors, including especially high tech ones, so called knowledge-based, innovative etc., is far ahead of the pace of development in primary sectors. This is not tantamount to their marginalisation in the economy and in modern society, because they continue to play important and difficult roles at this stage of development, or even roles that cannot be replaced by other sectors (such as, for example, agriculture, as a producer of raw materials for food production), but their developmental dynamics is giving way to many non-agricultural sectors.

To sum up, it should be stressed that over the period of around 70 years, there have been fundamental changes in the relation between agriculture and the entire economy. These changes were mainly related to systematic, however variable, decline in the potential of agriculture in the economy within different periods as a result of the

7 The highest share of land use in the socialised sector in Poland took place in the early 1980s, when it amounted to just over $25 \%$ of the total UAA area. At the time, it was the second lowest share of this sector in land use in socialist countries, after Yugoslavia.

8 According to the government, the share of the public sector in UAA amounts to $7.5 \%$ in 2018 . 
changing dynamics of growth. The factor that is specific to agriculture - land, evolved relatively the least. Land allocated for agricultural purposes reduced by about $25 \%$. Much deeper changes have taken place in the other two factors, universal from the point of view of the sectoral application, namely work (human resources) and capital. The share of labour resources decreased by $4 / 5$ and of capital by more than $4 / 5$. Thus, the ability of agriculture to accumulate developmental stimulation of non-agricultural sectors is also different today. This is demonstrated by the share of agriculture in creating added value for the economy.

\section{Agricultural production in the economy}

The main effect of manufacturing activity in the agricultural sector is the volume of material or utilitarian goods, i.e. global production. Global agricultural production is the sum of plant production, i.e. raw materials of plant origin and animal production, i.e. production of slaughter livestock and raw (unprocessed) products of animal origin, increased by the growth in livestock numbers. Global production is the most complete result of agricultural manufacturing activity. From the point of view of its purpose, it consists of commodity production (sales), natural consumption, internal consumption for production purposes and the growth (balance) of stocks and production in progress. It is also the basis for estimating the cumulative contribution of agriculture to the development of the whole economy. With the economic and civilizational growth, the share of agriculture in global economic output is decreasing. The main reason here is that production in non-agricultural sectors is growing faster than in agriculture, where the growth rate is predominantly determined by biological factors (rate of growth of yields and individual animal performance). Therefore, while the annual growth rate of production in nonagricultural sectors may be several percent or more, in agriculture, the long-term growth rate remains generally at the level of $1.52 .5 \%$. For example, world wheat production between 1996 and 2017 increased by an average of $1.5 \%$ per annum and milk production between 1970 and 2017 by $2.3 \%$ per annum (FAO, 2019), while the annual computer production rate has been well above $10.0 \%$ since the end of the last decade (2008), (Worldometers, 2020).

The consequence of these trends is that the share of agriculture in the global output of the economy is systematically falling. This is also visible in Polish agriculture. While until 1960 this share was at the level of 1/4 of the total output of the economy, the following decades brought a significant decline in this respect (Figure 5.). In $1970-1980$, this share remained at the level of $10-15 \%$, to fall below the lower threshold of this range after 1990. Since 2000, the share of agriculture in the total output of the Polish economy remained at $4.8 \%$, while in 2019 it amounted only 
to $3 \%$. However, due to the importance of agricultural production for consumers, its weight, both economic and social, is significantly "exceeding" the measurable contribution in value.

Figure 5. Share of agriculture in the global production of the national economy in Poland (period 1950-2019)

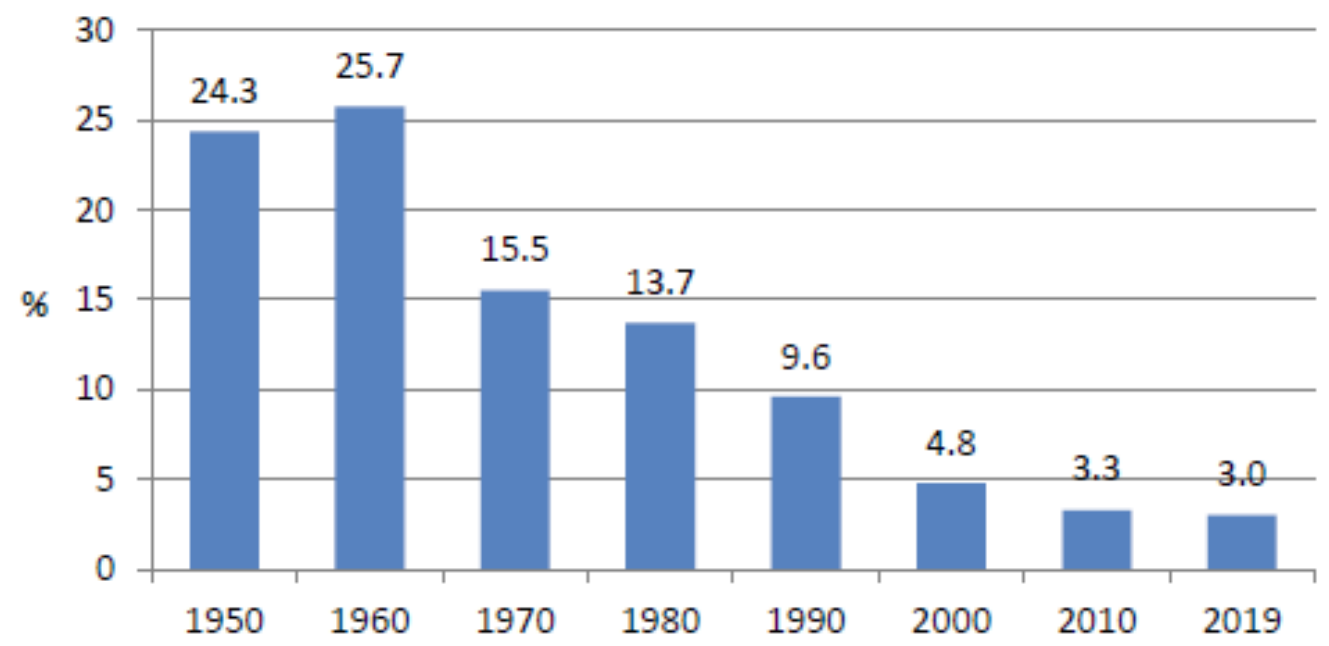

Source: Based on data from Statistics Poland, 2019.

Furthermore, it should be stressed that, with the decreasing share of agricultural production in the whole economy, the volume of agricultural products put onto the market is systematically increasing. Thus, between 1980 and 2018, wheat production increased for $133 \%$, freshwater fish for $82 \%$, live animals for $74 \%$, sugar beet for $42 \%$ and eggs for 35\% (Statistics Poland, 2019).

\section{Agriculture and national income}

The end result of the activities of national economy entities, including agricultural holdings, is an income constituting considerable added value in production and service provision. At the level of the national economy or a single sector, it may take the form of either domestic product (gross and net) ${ }^{9}$, or national income (gross and net), which is the sum of domestic product and foreign income (their balances). In mass statistics over a long period of time, i.e. until the 1990s, the basic category was GNI. Currently it is GDP and gross value added (GVA). The two categories: GNI

9 GDP is the sum of gross value added of all sectors, increased by taxes on products and reduced by subsidies on products. GVA is the difference between global production and intermediate consumption. 
and GDP were used in the analysis of the so-called accumulative contribution of agriculture to Poland's economic growth (Woś, 1979).

Figure 6. Share of agriculture in gross national income (GNI) / gross domestic product (GDP)* of Poland (period 1950-2019)

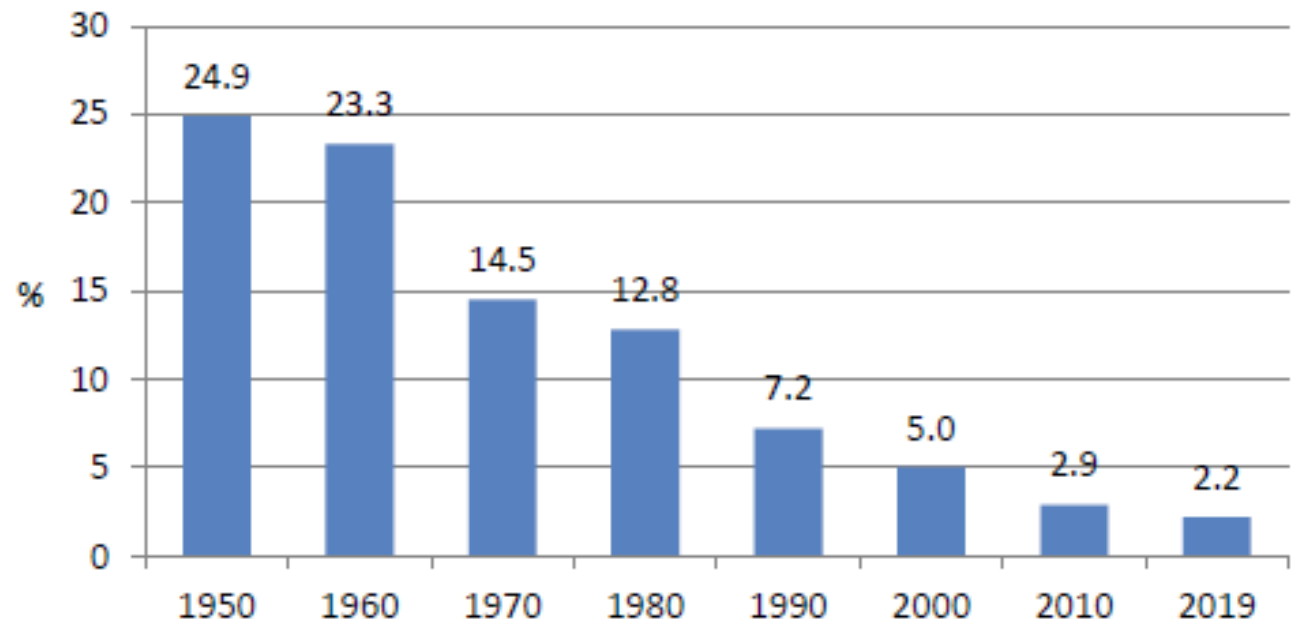

* for period 1950-1990 - GNI, for period 1990-2019-GDP.

Source: Based on data from Statistics Poland, 2019.

In general, agriculture's contribution to added value (or economic surplus) and its share in the total expenditure on economic growth tend to decrease with as the economy improves. This applies to both highly developed and developing countries, the decline in the share of agriculture takes place to a different extent however (Arendonk, 2015). This phenomenon explains many economic theories from both the classical school and development economics, or agrarianism itself. The reduction of the accumulative importance of agriculture in the economy is also visible in Poland. In the post-war period, agriculture was the source of about one quarter of the total national income. The following decades brought a systematic decline in this respect. In the 1970s and 1980 s it was already below $15 \%$, in the last decade of the $20^{\text {th }}$ century it was between 5-10\% and below 3\% after 2010 (Figure 6.).

The current level of the share of Polish agriculture in the economy is typical of "agricultural" highly developed countries such as Australia, Canada, South Africa, the Czech Republic, Finland and Portugal. In some countries, such as Austria, Belgium, Germany, Denmark, Ireland, Japan, Switzerland, the United Kingdom and the USA, the share oscillates around 1\% or even below this level, and is the highest in developing countries, such as: Sierra Leone $(57.4 \%$ in 2019), Guinea-Bissau (52.5\% in 2019), Chad (42.6\% in 2019), Central African 
Republic, Ethiopia, Liberia, Tanzania, Kenya, Mali, Niger (WB, 2020). The share of agriculture (and hunting, fishing and forestry) in GDP creation therefore varies from less than $1 \%$ to almost $60 \%$.

\section{Trade balance of agri-food products}

In the post-war period, trade in agri-food products, albeit small, remained of great importance for the advancement of national agriculture and entire economy. Nature of the links in this field has undergone significant changes. For many years, agri-food sector have not observe permanent product surpluses. Small quantities of goods were exported in order to obtain the currency which was essential for economic growth. Radical changes in Polish foreign trade in agri-food products took place during the period of systemic transformation (Woś, 2000), and later after accession to the EU. Faster growth of exports than imports led to essential change in the foreign balance of the agri-food sector.

Figure 7. Trade balance of agri-food products (period 2004-2019, in bln EUR)

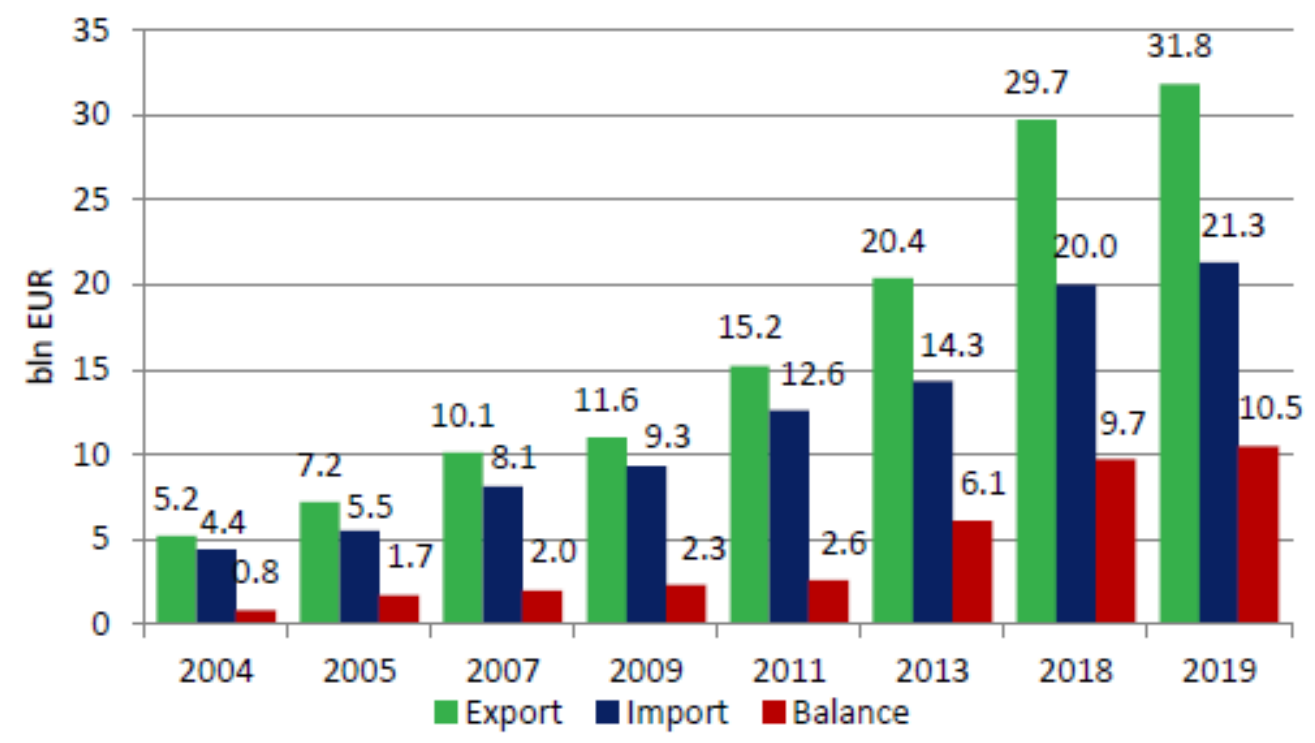

Source: MARD, 2020.

The balance of trade in agri-food products under market economy conditions is a measure of food self-sufficiency of a country. Agri-food products are a commodity group which, since Poland's accession to the EU, brings Poland a positive balance in foreign trade. In 2019, the total value of export amounted to 31.8 billion EUR, 6.1 times higher than in 2004, while the value of import amounted to 21.3 billion PLN, or for 4.8 times higher. It is also worth noting that Poland has a steadily 
growing surplus in trade in agri-food products, which reached 10.5 billion EUR in 2019, compared to 0.8 billion EUR in 2004 (Figure 7.).

\section{Agriculture and nutrition}

Nutrition has always been, and still is, the most important social and political problem, which is an indispensable condition not only for the human existence and food security, but also for further development, health and satisfaction, known as nutrition well-being (Berger, 2003).

Nutrition is defined as the provision of food to the human body, either in its natural or processed form, as a source of energy and nutrients for the maintenance of life and human psychophysical development. In this context, nutrition is identified with consumption, i.e. the amount and type of food consumed. In a broader aspect, nutrition is understood as a system of production and supply of food to meet the nutritional needs of the population of a given country (Gulbicka, 2000).

Supply of agricultural raw materials and food products at national level is determined as: supply $=$ production + import \pm stock difference - export

The demand for agricultural raw materials is determined not only by the population's consumption, but also their use for other purposes, e.g. for agricultural production (animal feed, grain for sowing) and processing into non-food products.

Food self-sufficiency is a measure of the possibility to feed the people from own production. Under the conditions of globalisation, the country's food self-sufficiency may be understood as the ability of the entire economy, i.e. both, agriculture, and the food industry, and other sectors, to meet domestic food demand. The place of food production is irrelevant - be it domestic or foreign producers (Sobiecki, 2007).

The indicator used by Eurostat was used to assess the food self-sufficiency of Poland. This indicator is expressed as a percentage and indicates the ratio of domestic production to domestic consumption of agricultural products:

- raw materials, such are cereals, potatoes, oil-crops, pulses, vegetables, fruits, fish \& seafood, eggs, milk and milk products in milk equivalent;

- pre-processed food products, such are bovine meat, pig meat, poultry meat, butter and sugar. 
Figure 8. Food self-sufficiency indicators in the range of products of plant origin (in 1960 and 2017, in \%)

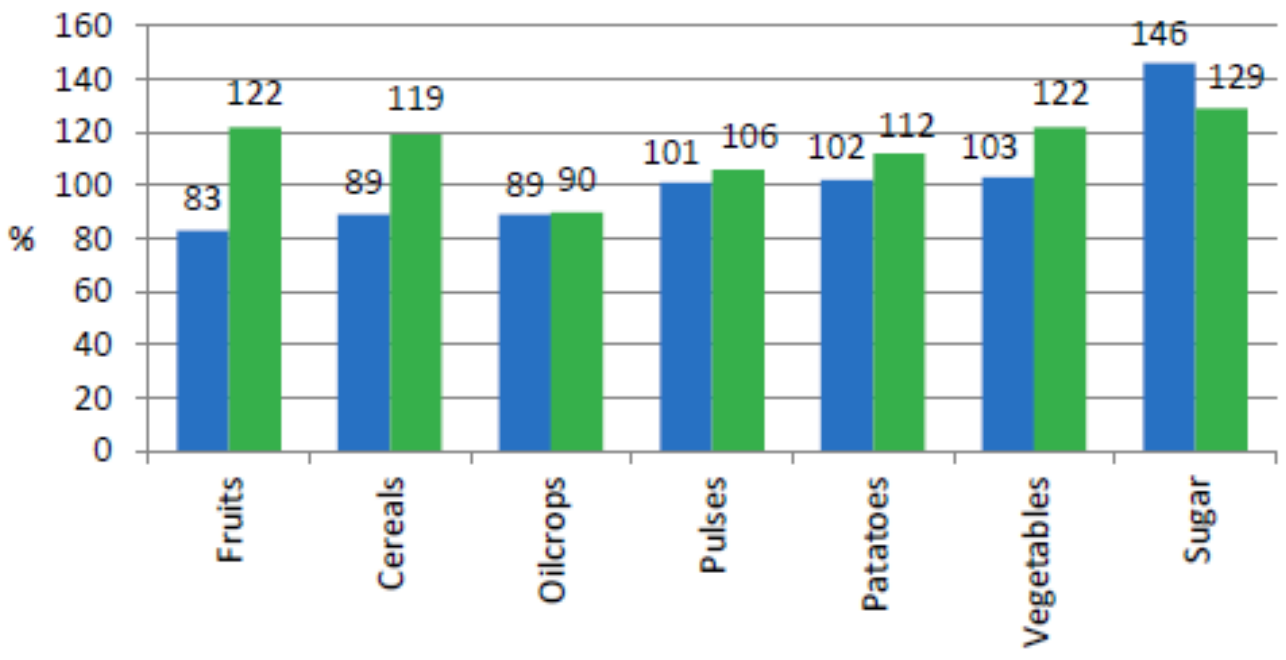

Source: Based on FAOSTAT, 2020.

Figure 9. Food self-sufficiency indicators in the range of products of animal origin (in 1960 and 2017, in \%)

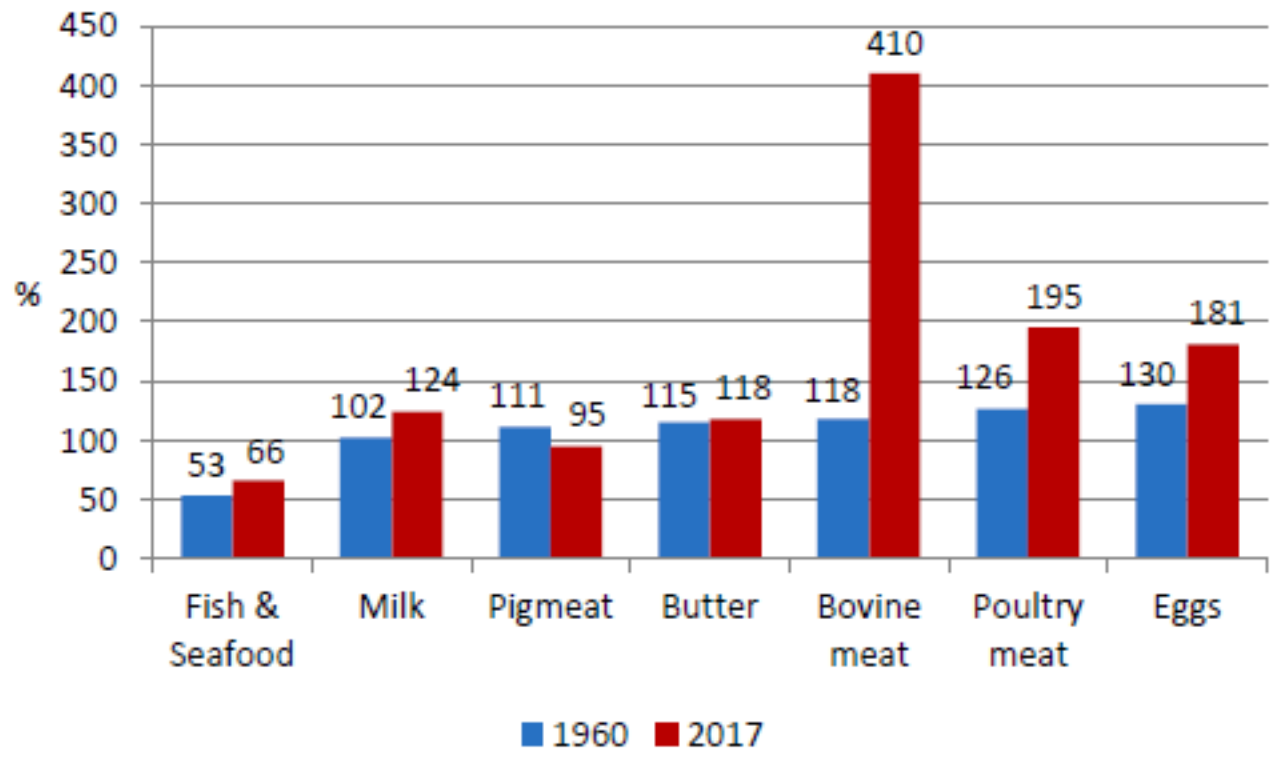

Source: Based on FAOSTAT 2020. 
In 2017 Poland has been achieved a high level of food self-sufficiency (over 100\%) in sector of bovine and poultry meat, eggs, sugar, milk and dairy products, vegetables, fruits, cereals, butter, potatoes and pulses (Figures 8. and 9.). Food self-sufficiency ratio for pig meat amounted to $95 \%$, oil-crops around $90 \%$ and fish $\&$ seafood around $66 \%$. Poland was not and is not selfsufficient with fish \& seafood and oil-crops, which must be imported.

Research results show that the Polish market offers most of the agri-food products necessary for proper human nutrition, what is indispensable condition for human development, physical fitness and intellectual development, as well as well-being and health.

\section{Trends in food consumption}

The shaping of food consumption patterns is strongly influenced not only by economic factors but also non-economic factors (including demographic, social, cultural), dietary recommendations leading to rational nutrition and new patterns of consumer behaviour, e.g. homogenisation, heterogenisation, ecology, virtualisation, servicisation, dematerialisation, deconsumption, individualisation, politicisation, mediatisation, presumption (Bywalec, 2010). The period of 1960-2017 experienced significant changes in the consumption of food in Poland.

Among products of plant origin, the consumption of fruits increased the most, by $232.1 \%$ (i.e. by $42.7 \mathrm{~kg}$ per capita), and to a lesser extent vegetable oils, by $75 \%$, pulses, by $42.9 \%$, sugar, by $31.8 \%$ and vegetables, by $28.6 \%$. The consumption of other products of plant origin decreased, potatoes, by $54.5 \%$ and cereal products, by 28.4\% (Table 1.).

The consumption of products of animal origin also recorded various changes. Greatest change concerned the consumption of poultry meat, as it increased over 15 times (i.e. by $27.2 \mathrm{~kg}$ per capita). The consumption of pig meat also increased, by $66.9 \%$, fish \& seafood, by $57.4 \%$, and to a lesser extent butter, by $15.2 \%$. The consumption of other products of animal origin decreased, bovine meat, by $72.5 \%$, animal fats (without butter), by $20.9 \%$, milk and dairy products, by $17.7 \%$ and eggs, by $13.3 \%$ (Table 1 .).

Supply of energy from food is an indicator used by the FAO for overall assessment of the nutrition level of the population in global dimension. This indicator presents the average daily energy supply available for an average country inhabitant in the analysed year and is expressed in kilocalories (kcal).

The analysis of FAO data shows that the availability of kilocalories per capita in Poland increased from 3,278 kcal in 1961-1963 to 3,474 kcal in 2015-2017, i.e. 
by $6 \%$ (Table 2.). Consumption of energy generated from products of plant origin increased by $3.5 \%$, while those come from products of animal origin increased by $12.6 \%$. In 2015-2017, according to FAO, the average dietary energy requirement (ADER) in the diet for a Polish citizen should be 2,523 kcal (FAO, 2020).

Table 1. Food consumption in Poland (in 1961-1963/2015-2017 a in kg, per capita/ per year)

\begin{tabular}{|l|r|r|r|r|r|r|r|}
\hline \multicolumn{1}{|c|}{ Item } & \multicolumn{1}{|c|}{$\mathbf{1 9 6 1 - 6 3}$} & $\mathbf{1 9 7 1 - 7 3}$ & $\mathbf{1 9 8 1 - 8 3}$ & \multicolumn{1}{c|}{$\mathbf{1 9 9 1 - 9 3}$} & $\mathbf{2 0 0 1 - 0 3}$ & $\mathbf{2 0 0 5 - 0 7}$ & $\mathbf{2 0 1 5 - 1 7}$ \\
\hline Cereals & 198.9 & 186.2 & 177.1 & 152.7 & 153.4 & 150.1 & 142.4 \\
\hline Potatoes & 219.9 & 185.8 & 156.0 & 143.9 & 130.6 & 127.1 & 100.0 \\
\hline Pulses & 1.4 & 1.9 & 1.8 & 2.3 & 1.9 & 1.8 & 2.0 \\
\hline Vegetables & 91.0 & 98.1 & 111.7 & 122.9 & 121.8 & 119.4 & 117.0 \\
\hline Fruits & 18.4 & 28.9 & 37.7 & 41.7 & 50.6 & 51.0 & 61.1 \\
\hline Sugar & 33.0 & 43.2 & 43.5 & 41.0 & 45.2 & 42.7 & 43.5 \\
\hline Meat total & 46.7 & 61.1 & 69.6 & 75.8 & 73.2 & 74.8 & 86.7 \\
\hline Bovine & 10.9 & 13.1 & 16.8 & 14.7 & 6.3 & 4.7 & 3.0 \\
\hline Pig meat & 32.6 & 42.9 & 37.9 & 51.3 & 48.4 & 50.0 & 54.4 \\
\hline poultry & 1.9 & 4.0 & 7.5 & 8.9 & 18.3 & 20.3 & 29.1 \\
\hline Fish/seafood & 6.8 & 12.6 & 12.5 & 10.1 & 9.0 & 9.5 & 10.7 \\
\hline Milk & 213.2 & 265.7 & 239.6 & 215.9 & 196.0 & 187.8 & 175.5 \\
\hline Eggs & 8.3 & 11.0 & 11.7 & 9.4 & 11.6 & 11.5 & 7.2 \\
\hline Animal fats & 20.4 & 25.0 & 26.5 & 17.3 & 16.1 & 14.4 & 17.8 \\
\hline Butter & 4.6 & 6.5 & 8.2 & 5.1 & 4.5 & 4.2 & 5.3 \\
\hline Vegetable oils & 4.0 & 5.8 & 6.4 & 8.9 & 12.1 & 11.9 & 7.0 \\
\hline
\end{tabular}

${ }^{a}$ In order to eliminate fluctuations in short-term changes in food consumption, the study used three-year averages over the period studied.

Source: Based on FAOSTAT, 2020.

Table 2. Energy and nutritional value of food in Poland (in 1961-1963 and 20152017 , per capita/per day)

\begin{tabular}{|l|r|r|r|r|r|r|}
\hline \multirow{2}{*}{ Item } & \multicolumn{2}{|c|}{$\begin{array}{c}\text { Energy } \\
\text { kcal/day }\end{array}$} & \multicolumn{2}{c|}{$\begin{array}{c}\text { Protein } \\
\text { g/day }\end{array}$} & \multicolumn{2}{c|}{$\begin{array}{c}\text { Fat } \\
\text { g/day }\end{array}$} \\
\cline { 2 - 7 } & $\mathbf{1 9 6 1 - 6 3}$ & $\mathbf{2 0 1 5 - 1 7}$ & $\mathbf{1 9 6 1 - 6 3}$ & $\mathbf{2 0 1 5 - 1 7}$ & $\mathbf{1 9 6 1 - 6 3}$ & $\mathbf{2 0 1 5 - 1 7}$ \\
\hline Grand Total & 3,278 & 3,474 & 97.0 & 101.2 & 89.1 & 128.8 \\
\hline Vegetal products & 2,376 & 2,458 & 53.9 & 46.6 & 17.8 & 44.4 \\
\hline Animal products & 902 & 1,016 & 43.1 & 54.6 & 71.3 & 84.4 \\
\hline
\end{tabular}

Source: Based on FAOSTAT, 2020.

The quality of food is determined by the amount of protein in the average daily food consumption. Total protein consumption in Poland in the observed period increased for $4.3 \%$. Consumption of protein of plant origin decreased for $13.5 \%$, while protein of animal origin increased for $26.7 \%$. 
As the level of the country's social and economic development increases, the share of animal protein in the total amount of protein consumed increases. This results in a significant increase in demand for animal protein products. In the early $1960 \mathrm{~s}$, the share of animal protein in total protein consumption was 44.4\%, while in 2015-2017 it was $54 \%$. However, the increase in the consumption of red meat, and especially pig meat, has a negative impact on the health of the society (the consumption of pig meat in the analysed period increased by as much as $66.9 \%$ ). Specialists in human nutrition recommend, for health reasons, limiting the consumption of meat with a high fat content, including pork, in favour of consumption of leaner types of meat, including poultry meat, rabbit meat, venison and fish, especially marine fish.

Significant changes in the consumption of animal products have resulted in an increase in the fat content of the average daily ration in Poland. Total fat consumption increased by $39.7 \mathrm{~g}$ per capita per day, i.e. by $44.6 \%$, including fats of plant origin, 2.5 times, and fats of animal origin, for $18.4 \%$.

According to the dietary recommendations recommended by international organisations dealing with the issue of feeding the population, including FAO and WHO, and Polish specialists in human nutrition, the share of energy obtained from protein consumption in the energy value of daily food consumption should be $10-15 \%$, fats, $25-30 \%$, and carbohydrates, the rest, i.e. $55-65 \%$, including refined sugar, about $10 \%$. These recommendations apply to highly and medium developed countries.

Within the period 2015-2017, the share of energy from protein consumption in total energy consumption in Poland was in line with nutritional recommendations and it amounted up to $11.7 \%$, while the share of energy obtained from fat consumption exceeded the upper limit of the recommended standard and amounted up to $33.4 \%$. The share of energy from sugar consumption was also inconsistent with the dietary recommendations and amounted up to $13.7 \%$. The high share of fats and sugar in the food consumed indicates an unreasonable diet for the population, which is not in line with the principles of proper nutrition.

\section{Summary: Instead of Conclusion}

The period of almost 70 years analysed here was a time of exceptional changes for Polish agriculture. It consisted primarily in the fact that the potential of agriculture in the economy, however variable over the years, has been systematically declining. The factor that is specific to agriculture, land, evolved relatively the least. Land allocated for agricultural purposes reduced for about one quarter. Much deeper changes have taken place in the other two factors, namely work (human resources) 
and capital. The share of labour resources decreased by $4 / 5$ and of capital even by more than $4 / 5$. As a result, the accumulative importance of agriculture in the economy has been continuously declining. Therefore, while in the post-war period, agriculture was the source of about a quarter of the total national income, after 2010 it dropped below 5\%.

In the export of the agri-food sector, Poland recorded an undoubted success, which is confirmed by its nearly fivefold increase since accession to the European Union, to 31.8 billion EUR, and its share of total export increased from $8.8 \%$ to $13.2 \%$. The high quality and recognition of Polish food products is evidenced by the fact that over $80 \%$ of export go to more demanding foreign consumers in economically developed countries.

Food consumption has also undergone dynamic changes. Total food consumption in Poland decreased by $91 \mathrm{~kg}$ per capita, which was a result of a decrease in the consumption of products of plant origin, from $567 \mathrm{~kg}$ in 1961-1963 to $473 \mathrm{~kg}$ in 20152017 (by $94 \mathrm{~kg}$, i.e. by 16.6\%) and a slight increase in the consumption of animal products (by $2.5 \mathrm{~kg}$ ). Within the whole analysed period, the consumption of products of plant origin exceeded the consumption of animal products.

Positive changes in the structure of food consumption include an increase in the consumption of fish \& seafood, poultry meat and fruits, while negative changes include a decrease in the consumption of vegetables, milk and milk products and an increase in the consumption of sugar and pig meat.

The rationalisation of food consumption is linked, above all, to a much higher consumption of fruits, vegetables, pulses, milk and milk products and fish \& seafood, and to a much lower consumption of sugar and animal fats. Implementation of the above nutritional recommendations may bring food consumption in Poland closer to a healthy food consumption pattern, such as the Mediterranean diet, which is considered to be the healthiest food consumption pattern in the world.

Domestic agriculture has a decisive impact on the nutrition of the population in Poland. It has sufficient production potential to produce agri-food raw materials at the level recommended for healthy diets (except for fish and seafood).

The changes that took place in the position of agriculture in the Polish national economy after 1950 were dynamic and multidirectional. In the period up to 1956, they were mainly determined by the policy of collectivization and attempts at administrative liquidation of individual farms. This policy was changed after the political and social breakthrough of 1956 . The next period is an attempt to preferentially treat the socialized economy in agriculture (PGR, agricultural production cooperatives) and to 
systematically reduce the economic conditions for the functioning of peasant farms. This policy led to an economic recession, as a result of which, in the years 19601970 , the grain harvest increased by only $7.5 \%$, the cow population by $3.4 \%$, and the pig population by $6.3 \%$ (Statistics Poland, 2019). The improvement of operating conditions for peasant farms took place after 1970, and fully after 1990.

Currently, agriculture is an important part of the Polish economy, despite the fact that, as stated above, there is a relative decline in its share, measured both by the value of production potential and economic effects. The analysis of the market advantages of individual industries indicates that it is Polish agriculture, and no other economic sectors, that have a chance to face competition on regional and global markets.

\section{References}

1. Arendonk van, A. (2015). The development of the share of agriculture in GDP and employment. A case study of China, Indonesia, the Netherlands and the United States. Leibniz Institute of Agricultural Development in Transition Economies, Wageningen University, the Netherlands, retrieved at: https://edepot. wur.nl $/ 342795,9^{\text {th }}$ September 2020.

2. Berger, S. (2003). Problemy żywieniowe świata $i$ organizacje międzynarodowe. In: Gawęcki, J., Hryniewiecki, L. (Eds.). Żywienie człowieka. Podstawy o żywieniu. PWN, Warszawa, Poland.

3. Byrne, J. J. (1955). Agriculture in the National Economy. Studies: An Irish Quarterly Review, 44(173):17-40.

4. Bywalec,C.(2010).Konsumpcja a rozwójgospodarczyispołeczny. Wydawnictwo C. H. Beck, PWN, Warszawa, Poland.

5. Earl, A. S., Boehlje, M., Boyd, R. D., Buttel, F. H., Flora, C. B., Goldmark, P. J., Kirschenmann, F., Zilberman, D. (2002). Drivers of Structural Change, Changes in Knowledge and Information, Implications for Policy. In: Publicly Funded Agricultural Research and the Changing Structure of U.S. Agriculture, The National Academy Press, Washington, DC, USA, retrieved at: www.nap. edu/read/10211/chapter/7, $23^{\text {rd }}$ June 2020.

6. FAO (2019). Global Trends in GDP, Agriculture Value Added, and FoodProcessing Value Added (1970-2017). FAO, Italy, Rome, retrieved at: www.fao. org/economic/ess/ess-economic/gdpagriculture/en/, 20 ${ }^{\text {th }}$ August 2020.

7. FAO (2020). Food security indicators. FAO, Italy, Rome, retrieved at: www.fao. org/economic/ess/ess-fs/ess-fadata/en/\#.X4QIs1UzZhE, 17 th September 2020. 
8. FAOSTAT (2020). Data set related to agriculture and nutrition in Poland. Portal of FAOSTAT - Food and Agriculture Organization, Rome, Italy, retrieved at: www.fao.org/faostat/en/\#data/FBSH, 23 ${ }^{\text {rd }}$ September 2020.

9. Gautam, M., Faruqee, R. (2016). Dynamics of Rural Growth in Bangladesh: Sustaining Poverty Reduction. Series Directions in Development: Agriculture and Rural Development, World Bank, Washington, DC, USA.

10. Grigg, D. (1992). Agriculture in the World Economy: an Historical Geography of Decline. Geography, 77(3):210-222.

11. Gulbicka, B. (2000). Wyżywienie polskiego spoleczeństwa w ostatniej dekadzie XX wieku. Studia i Monografie, no. 96. IERiGŻ-PIB, Warszawa, Poland.

12. Hayami, Y., Ruttan, V. (1985). Agricultural Development: An International Perspective. Johns Hopkins University Press, Baltimore, USA.

13. Hazell, O., Wood, S. (2008). Drivers of change in global agriculture. Philosophical Transactions of Royal Society B, 363:495-515.

14. Journal of Laws (2007). Act of $26^{\text {th }}$ January 2007 on payments under direct support schemes, no. 35, Item 217.

15. Kusz, D., Gędek, S., Kata, R. (2013). Egzogeniczne uwarunkowania inwestycji w rolnictwie polskim. IX Kongres Ekonomistów Polskich, Polskie Towarzystwo Ekonomiczne, Warsaw, Poland, retrieved at: www.pte.p1/kongres/referaty.pdf, $19^{\text {th }}$ August 2020.

16. Lains, P., Pinilla, V. (2009). Introduction. In: Lains, P., Pinilla, V.(Eds.)Agriculture and Economic Development in Europe since 1870, Routledge, London, UK.

17. MARD (2020). Polski handel zagraniczny artykułami rolno-spożywczymi w $2019 r$. Ministry of Agriculture and Rural Development, Warsaw, Poland, retrieved at: www.gov.pl/web/rolnictwo/polski-handel-zagraniczny-artykulamirolno-spozywczymi-w-2019-r, 22 ${ }^{\text {nd }}$ September 2020.

18. Meijerink, G., Roza, P. (2007). The role of agriculture in development. Markets, Chains and Sustainable Development Strategy and Policy Paper, no. 5, pp. 1-39. Stichting DLO, Wageningen, the Netherlands, retrieved at: www.boci.wur.nl/ UK/Publications/, $23^{\text {rd }}$ June 2020.

19. Sobiecki, R. (2007). Globalizacja a funkcje polskiego rolnictwa. SGH, Warszawa, Poland.

20. Statistics Poland (2019). Statistical Yearbook of the Republic of Poland 2019. Statistics Poland, Warsaw, Poland, retrieved at: https://stat.gov.pl/, $24^{\text {th }}$ June 2020. 
21. Statistics Poland (2020). Statistical Yearbook of Agriculture 2019. Statistics Poland, Warsaw, Poland, retrieved at: https://stat.gov.pl/, $24^{\text {th }}$ June 2020.

22. Statistics Poland (2020b). Land use. Portal of Statistics Poland, Warsaw, Poland, retrieved at: https://bdl.stat.gov.pl/BDL/dane/podgrup/temat, $13^{\text {th }}$ August 2020.

23. Thiagarajan, B. (2020). Drivers for Growth of Indian Agriculture. Portal of the Confederation of Indian Industry (CII), New Delhi, India, retrieved at: www. ciiblog.in/economy/drivers-for-growth-of-indian-agriculture/, $23^{\text {rd }}$ June 2020.

24. WB (2020). Agriculture, forestry, and fishing, value added (\% of GDP). Portal of World Bank (WB), Washington DC, USA, retrieved at: https://data.worldbank. org/indicator/NV.AGR.TOTL.ZS, $21^{\text {st }}$ September 2020.

25. Worldometers (2020). Computers sold this year. Portal of Worldometers, retrieved at: www.worldometers.info/computers/, $15^{\text {th }}$ August 2020.

26. Woś, A. (1979). Zwiqzki rolnictwa z gospodarka narodowa. PWRiL, Wydanie II uzupełnione, Warszawa, Poland.

27. Woś, A. (2000). Rolnictwo polskie 1945-2000. Porównawcza analiza systemowa. IERiGŻ, Warszawa, Poland. 